\title{
Foreword
}

\section{THE RULE OF LAW AND THE INTERNATIONAL RULE OF LAW}

Under Article 2 of the Treaty on European Union, one of the values on which the Union is founded is the rule of law. Indeed, the European Union can be regarded as totally dependent on the rule of law, notably in its relations with its Member States, where it lacks other relevant instruments of cohesion. As has been demonstrated over many years, the Court of Justice of the European Union has a central role in this respect, ensuring the implementation of the rule of law in the interpretation and application of the Treaties.

The European Union has also developed an important role, beyond the Member States, in the international legal order. It has developed over the years a wide treaty-making power; it has concluded many treaties - some together with its Member States, some exclusively; it is a member, in its own right, of many international organisations; and it is a major subject of international law.

The rule of law also occupies a fundamental role in the international relations of the EU. And by Article 3(5) of the Treaty, the Union is required to contribute to the strict observance and the development of international law, including respect for the principles of the United Nations Charter. As it might be expressed, the Union is required to uphold the international rule of law.

This book has as its focus important recent developments in the relations of the European Union with international law.

Here it is appropriate to focus on the most recent developments, as highlighted in this book. The main focus is on recent cases of the CJEU; two issues in particular stand out and raise several fundamental questions, all of considerable importance for the relationship of the European Union with the rule of law.

\section{ACCESSION BY THE EUROPEAN UNION TO THE EUROPEAN CONVENTION ON HUMAN RIGHTS}

As long ago as 1979 the European Commission proposed that the European Community should accede to the European Convention on Human Rights. The 
issue was referred by Belgium to the Court of Justice, which held that such accession would require an explicit Treaty amendment. Such an amendment was made by the Treaty on European Union as amended by the Lisbon Treaty, which not merely empowered, but obliged, the European Union to accede to the Convention. In due course an agreement on accession was successfully negotiated. The Court had been involved in the negotiations and had secured important safeguards for the legal order of the Union. However, the Court, going much further than the Opinion of Advocate General Kokott, raised what seemed novel and, in its view, fundamental objections. It objected to what it saw as the Strasbourg Court having the last word on the interpretation of EU law, without the Court of Justice having its say. The Court's objection is based on the notion of the 'autonomy' of EU law. While I take no position here on that objection, it might be noted that such situations are not unusual in international dispute settlement systems: international courts may decide questions which have not been raised before national courts. Moreover the ECHR itself imposes a requirement, before a case can be considered by the European Court of Human Rights, of the exhaustion of domestic remedies.

But the objection of the Court of Justice raises a further question: it might be said that an international court or tribunal, and the European Court of Human Rights here, does not in any circumstances make a definitive and authentic interpretation of municipal law - including European Union law. Rather, the international courts interpret the treaties which they are required to apply. In the judgments of international courts, statements of municipal law (including EU law) are to be regarded in the same way as findings of fact. Those interpretations in no way bind other courts in future cases. Thus the Strasbourg Court interprets the Convention, and rules on how the Convention so interpreted applies in all the circumstances of the case. In relation to the European Union, the Strasbourg Court would thus interpret the Convention and decide whether, on the basis of all the facts, including the way in which any provisions of national or EU law were applied by the national or EU authorities, there has been a breach of the Convention as so interpreted. On that view, a decision of an international court or tribunal containing a finding on EU law does not in any event affect the 'autonomy' of the EU legal order.

\section{INTERNATIONAL DISPUTE SETTLEMENT: ACHMEA AND CETA}

Going even further, and much discussed in this book, is the Achmea judgment. The main issue was, in essence, whether a system of international arbitration mechanism for the settlement of Investor-State disputes, under which questions of EU law could not be referred to the Court of Justice, was compatible with EU law. The Court's ruling, going against the opinion of Advocate 
General Melchior Wathelet, also raises some new questions. In particular the Court's reliance, in support of its conclusion, on Articles 267 and 344 TFEU, is novel and has proved controversial.

Moreover, in contrast to earlier opinions of the Court, for example on the draft EEA Agreement, on the proposed European Patent Court, and on EU accession to the ECHR, all of which examined proposed future agreements, the ruling in Achmea concerned past proceedings and could be read as overturning a well-established and widely used mechanism for the settlement of international disputes which had been established for apparently good reasons and had been functioning for many years. The Court did not rule on the consequences of its judgment for past or for ongoing procedures. But once the judgment was given, the referring court quashed the arbitral award at issue in the main proceedings.

Moreover, a declaration subsequently adopted by certain Member States at the instigation of the European Commission stated that the Court's ruling had immediate effect so as to invalidate ongoing procedures and even past awards. While such declarations have no effect as a matter of law, they may have some impact in practice. Here the question has been raised whether such retroactive consequences are consistent with fundamental rights, or indeed - of particular importance for the subject of this book - with the international rule of law.

These issues remain live. The more recent CETA Opinion of the Court of Justice - here in line with the opinion of Advocate General Bot - appears to retreat partially from the earlier case-law. In particular, it accepts that a dispute settlement mechanism can be compatible with EU law even without any involvement of the Court of Justice; and it recognises that questions of EU law can be decided by an international tribunal as a matter of fact.

It has even been suggested that the CETA Opinion might be a basis for the Court of Justice to re-consider the issue of EU accession to the ECHR. At all events it seems likely that this very important area of law on the relationship between EU law and international dispute settlement mechanisms will continue to evolve: it is to be hoped in the right direction. As will be apparent, it raises central questions on the observance by the European Union of the international rule of law.

Sir Francis G. Jacobs 